\title{
The usefulness of soluble transferrin receptor (sTfR) in differentiating anemia occurring in young children
}

\author{
Barbara Kamer ${ }^{1}$, Elżbieta Dółka1, Renata Pasowska1, Ewa Świątkowska² \\ ${ }^{1}$ Second Department of Pediatrics and Allergology, Polish Mothers' Memorial Hospital \\ - Research Institute, Lodz, Poland \\ ${ }^{2}$ Department of Laboratory Diagnostics, Polish Mothers' Memorial Hospital - Research Institute, \\ Lodz, Poland
}

\begin{abstract}
We evaluated the usefulness of soluble transferrin receptor (sTfR) and of the sTfR/log ferritin index $(\mathrm{sTfR} / \log \mathrm{F})$ in the differentiation of anemia in young children. 96 children, aged 6-36 months, were examined. From these, four groups were distinguished: 1 - (IDA): 33 children with anemia due to iron deficiency; $2-$ (IA): 19 children with infectious anemia without iron deficiency; 3 - (IA + ID): 16 children with infectious anemia and iron deficiency; and 4 - a comparator group (CG): 28 healthy children without iron deficiency. The soluble transferrin receptor, hematological indices and iron balance were evaluated and the sTfR/logF was calculated for each examined child. It was proved that the mean values of sTfR and sTfR/logF were substantially higher in children with anemia due to iron deficiency, and in those with infectious anemia and iron deficiency, vs. those with infectious anemia or in healthy children. This suggests that both sTfR and the sTfR/logF are good indicators of iron deficiency and could be useful in the differential diagnostics of anemia, especially in young children. (Folia Histochemica et Cytobiologica 2012, Vol. 50, No. 3, 473-479)
\end{abstract}

Key words: soluble transferrin receptor, anemia, young children

\section{Introduction}

Anemia is a significant medical problem often diagnosed in infants and young children. There are many causes of anemia; the most frequent of these are acute and chronic infections, iron deficiency, or both factors simultaneously. Identifying the cause is a very important step in anemia management, as it determines the treatment to be applied [1-4]. Iron balance evaluation in patients with anemia is based on complex hematological and biochemical assays, including serum iron concentration $(\mathrm{Fe})$, unsaturated iron-binding capacity (UIBC), ferritin concentration (F), and calculating the total iron-binding capacity (TIBC) and

\footnotetext{
Correspondence address: B. Kamer,

Second Department of Pediatrics and Allergology,

Polish Mother's Memorial Hospital — Research Institute,

Rzgowska Str. 281/289, 93-338 Lodz, Poland;

tel.: + 484227120 91, fax: + 484227113 86;

e-mail: bkamer@wp.pl
}

transferrin saturation index (TSI). As yet, there is no single laboratory test to recognize iron deficiency [5-8]. Over recent years, serum concentrations of soluble transferrin receptor have been investigated as a marker of iron status.

The transferrin receptor is a transmembrane glycoprotein, made up of two identical subunits connected by a pair of disulphide bridges, forming a molecule of $190 \mathrm{kDa}$ [9-11]. The role of the transferrin receptor is to insert iron into a cell center by joining transferrin molecules in the blood [9, 12]. Among healthy adults, about $70-80 \%$ of the receptor's systemic pool is on the erythroid cells [13-15].

Present in blood serum, soluble transferrin receptor, first described by Kohgo [16] in 1986, is a shortened extracellular domain of the whole cellular receptor, formed in result of its proteolitic disintegration $[17,18]$. Many authors have described correlations observed between the soluble transferrin receptor concentration and the number of cellular receptors [6, 10, 14, 15, 19]. R'zik et al. [20] proved 
that soluble transferrin receptor was a fairly constant fraction that constituted about $6 \%$ of tissue receptor. It has been documented that an intensification of erythropoesis [14-16] and iron status [21] had the biggest influence on soluble transferrin receptor levels. Thus, numerous studies have been and are still being carried out on the usefulness of sTfR in the diagnostics of iron deficiency $[13,21,22]$ in order to differentiate iron deficiency-caused anemia from that which arises in the course of acute or chronic inflammatory disease [23]. Some research has also been done to monitor the effects of either recombinant human erythropoietin treatment [24] or of supplementary treatment with iron preparations [25].

It has been proved that serum sTfR concentrations substantially increase in the course of anemia due to iron deficiency, but remain unchanged in anemia caused by inflammatory disease. Moreover, it seems that the calculated sTfR/logF index is more useful vs. sTfR alone in the diagnostics of iron deficiency in patients with inflammatory disease [26, 27].

The aim of this study was to evaluate the diagnostic usefulness of serum sTfR concentrations and of the sTfR/ $\log F$ to differentiate iron deficiency-caused anemia from inflammatory anemia in young children.

\section{Material and methods}

This study was carried out on 96 children, their ages varying from 6 to 36 months, hospitalized in 2002-2008 at the Second Department of Pediatrics and Allergology of the Polish Mother's Memorial Hospital - Research Institute in Lodz. There were 68 boys $(70.8 \%)(\mathrm{p}<0.001)$ in the examined group, and 28 girls $(29.2 \%)$. There were 43 infants aged $6-12$ months (44.8\%), 40 children aged $1(41.7 \%)$ and $13(13.5 \%)$ aged 2. The following assays were carried out for each child:

- the erythrocyte index with a Bayer H1 hematological analyzer. The obtained results were referred to the standards by Lanzkowsky [28];

- iron balance status (biochemically determined), including iron concentration and unsaturated iron-binding capacity (UIBC) in blood serum. Both factors were determined by spectrophotometry on a Cobas Integra analyzer (Roche) and serum ferritin concentrations by the immunoenzymatic method on an Immulite 1000 analyzer (DPC), where the manufacturer's reference values were regarded as standard. Those values included: serum iron concentration at $43-184 \mu \mathrm{g} / \mathrm{dl}$, unsaturated iron-binding capacity at $112-346 \mu \mathrm{g} / \mathrm{dl}$, and ferritin concentration at $6-159 \mathrm{ng} / \mathrm{ml}$ in girls and $28-397$ $\mathrm{ng} / \mathrm{ml}$ in boys;

- transferrin saturation index (TSI), calculated by the following formula: iron concentration divided by the total iron-binding capacity (TIBC) and multiplied by 100 . The TSI $>16 \%$ values were regarded as correct ones;
- soluble transferrin receptor concentrations by the kinetic nephelometry method, on a BN Prospec nephelometer (DADE Behring) with DADE Behring reagent, containing monoclonal antibodies. The results were expressed in $\mathrm{mg} / \mathrm{l}$ and compared to the manufacturer's standard, i.e. $0.83-1.76 \mathrm{mg} / \mathrm{l}$. Since the standards had been developed from a group of 456 adults from Central Europe, with no child population, the results of the study were referred to the results of the children from the comparator group.

Moreover, some authors have suggested that a simultaneous evaluation of the soluble transferrin receptor and ferritin concentrations can diagnose iron deficiency better than sTfR concentration in children alone. Thus, the soluble transferrin receptor index $(\mathrm{sTfR} / \log \mathrm{F})$ was calculated according to the following formulas: serum receptor concentration divided by ferritin concentration logarithm and multiplied by 100 [29, 30].

The results were statistically analyzed. Gauss test was used to confirm the normality of distribution of all the studied features. A comparison of the mean values among the three age groups of the comparator group was performed with the single factor ANOVA/Fisher's test, while comparisons among groups were made with the Student's test. The relationships among the features were described by Pearson's correlation coefficient (r). Statistical significance of the calculated correlation coefficients was verified at the level of $|r| \geq 0.4$. The study test was compared with a reference test, taking into account the characteristics parameters (sensitivity, specificity, accuracy). The cut-off points were the highest values of the range obtained in the children from the comparator group.

The Commission of Ethics of Scientific Research at the Polish Mothers' Memorial Hospital - Research Institute in Lodz approved the study protocol.

The parents of all the qualified children gave their consent for the participation of their children in the study.

\section{Results}

Medical history, physical examination and hematological and biochemical assays distinguished the following three groups: group 1 (IDA): 33 children with iron deficiency anemia; group 2(IA): 19 children with infectious anemia without iron deficiency; and group 3: 16 children with acute airways infection and iron deficiency (IA + ID - infectious anemia and iron deficiency). A comparative group (CG) consisted of 28 healthy children with regular hematological and biochemical results.

Among the healthy children (CG), the following three age brackets were distinguished: $6-12$ months, 13-24 months and 25-36 months, with sex consideration in each bracket. No statistically significant differences were observed in terms of mean soluble 
Table 1. Comparison of average values of concentration of soluble transferrin receptor (sTfR) and sTfR/logarithm of ferritin index (sTfR/logF index) in examined children

\begin{tabular}{|c|c|c|c|c|c|c|c|c|}
\hline & \multicolumn{2}{|c|}{ IDA (1) } & \multicolumn{2}{|c|}{ IA (2) } & \multicolumn{2}{|c|}{ IA + ID (3) } & \multicolumn{2}{|c|}{ CG (4) } \\
\hline & $\begin{array}{c}\text { sTfR } \\
{[\mathrm{mg} / \mathrm{l}]}\end{array}$ & $\begin{array}{l}\text { sTfR/logF } \\
\text { index }\end{array}$ & $\begin{array}{c}\text { sTfR } \\
{[\mathrm{mg} / \mathrm{l}]}\end{array}$ & $\begin{array}{c}\text { sTfR/logF } \\
\text { index }\end{array}$ & $\begin{array}{c}\text { sTfR } \\
{[\mathrm{mg} / \mathrm{l}]}\end{array}$ & $\begin{array}{l}\text { sTfR/logF } \\
\text { index }\end{array}$ & $\begin{array}{l}\text { sTf R } \\
{[\mathrm{mg} / \mathrm{l}]}\end{array}$ & $\begin{array}{c}\text { sTfR/logF } \\
\text { index }\end{array}$ \\
\hline Mean & 4.56 & 9.98 & 1.89 & 0.63 & 3.71 & 4.57 & 1.87 & 1.22 \\
\hline SD & 2.35 & 15.19 & 0.39 & 0.31 & 1.85 & 3.30 & 0.31 & 0.25 \\
\hline Min & 2.33 & 2.07 & 1.26 & -0.03 & 1.55 & 0.70 & 1.36 & 0.71 \\
\hline Max & 13.3 & 75.5 & 2.63 & 1.10 & 8.82 & 13.7 & 2.48 & 1.76 \\
\hline $\begin{array}{l}\text { Groups } \\
\text { Statistical significance } \\
\mathrm{p}<0.01\end{array}$ & \multicolumn{2}{|c|}{2 and 4} & \multicolumn{2}{|c|}{1 and 3} & \multicolumn{2}{|c|}{2 and 4} & \multicolumn{2}{|c|}{1 and 3} \\
\hline
\end{tabular}

Examined groups of children: IDA — iron deficiency anemia; IA — infectious anemia; IA + ID — infectious anemia with iron deficiency; $\mathrm{CG}$ - control group
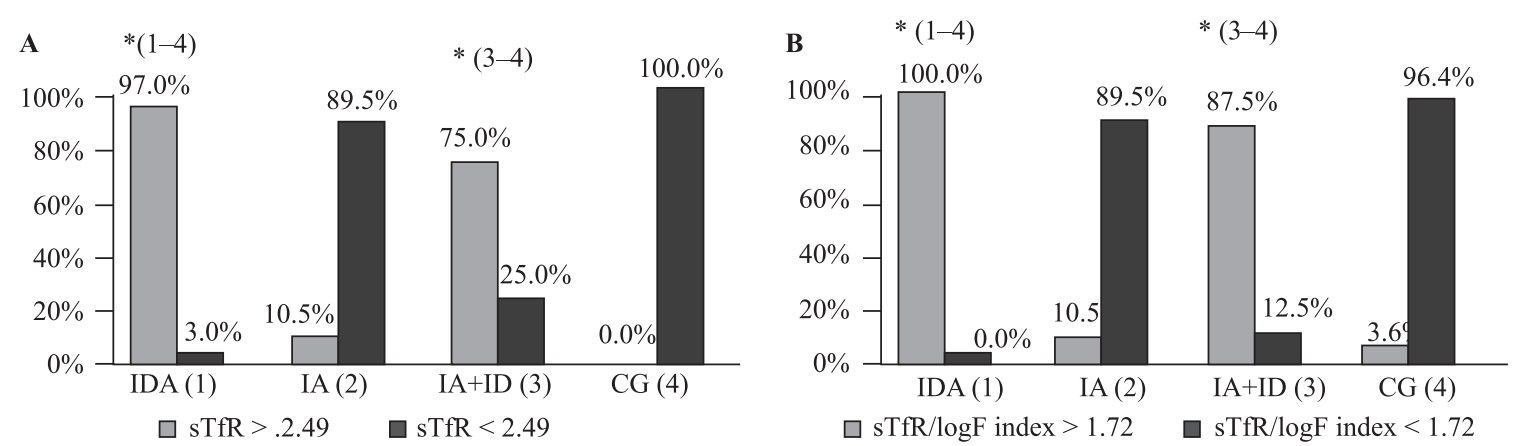

Figure 1. Percentage of children with increased soluble transferrin receptor (sTfR) concentration and value of sTfR/ /logarithm of ferritin index (sTfR/logF index) in the examined groups. IDA - iron deficiency anemia;

IA — infectious anemia; IA + ID — infectious anemia with iron deficiency; CG — control group

transferrin receptor values, even when the age and sex of the examined children were taken into account. Consequently, neither sex nor age was considered in the analysis of sTfR concentrations of the examined children with anemia.

See Table 1 for sTfR concentrations and sTfR/logF results in the examined children.

The mean values of sTfR concentration and of the sTfR/logF were significantly higher in IDA and IA + ID children vs. those with infectious anemia and the healthy CG subjects. It should be noted that the two groups without iron deficiency presented similar values.

Due to the fact that the applied manufacturer's sTfR concentration reference values concerned adults, and that no standardized norms for STfR concentration in children had been developed, the average concentration \pm 2 standard deviations in the children from the comparator group were treated as reference values: $1.87 \pm 0.62 \mathrm{mg} / \mathrm{l}$. Thus, the correct values were $1.25-2.49 \mathrm{mg} / \mathrm{l}$. In the same way, based on the results of the CG children, a range of reference values for the sTfR/logF was developed, as 0.71-1.72.
Then, the results of individual measurements in the examined children were compared to the estimated range of reference values. See Figure 1 for individual STfR concentrations vs. estimated reference values in particular groups of examined children.

It has to be emphasized that no sTfR concentration above $2.49 \mathrm{mg} / \mathrm{l}$ was found in any child from the comparative group. However, in children with iron deficiency anemia (IDA) and infectious anemia and iron deficiency (IA + ID), serum sTfR concentrations were higher than those in the reference group and with infectious anemia. The differences between IA and CG children were not statistically relevant.

High values of the sTfR/logF (above 1.72) were found in $3.6 \%$ of the examined CG children and in $10.5 \%$ of the IA children. Nevertheless, the percentage of children with incorrect sTfR/logF values was statistically higher among the IDA and IA + ID subjects vs. those without iron deficiency from either group (IA and CG).

The subsequent stage of the study focused on relationships between soluble transferrin receptor concentrations and biochemical iron balance index val- 
Table 2. Analysis of correlations between both soluble transferrin receptor (sTfR) concentration and the value of sTfR/ /logarithm of ferritin index (sTfR/SF index) and biochemical parameters of iron

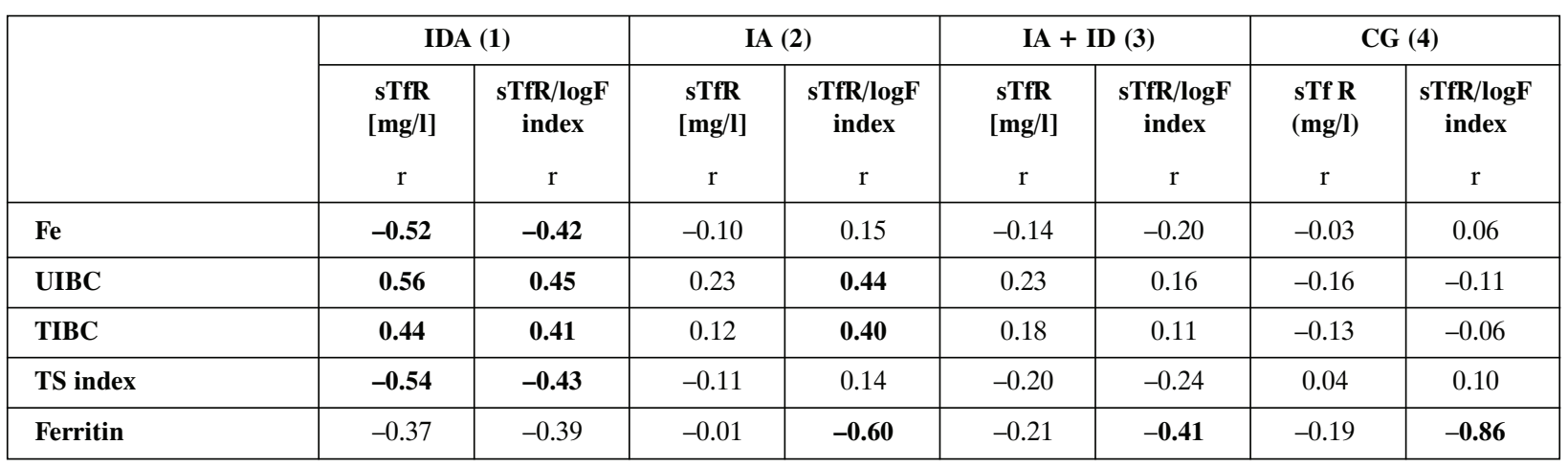

$\mathrm{r}$ - Pearson correlation coefficient, statistical significance $|\mathrm{r}| \geq 0$.4. Examined groups of children: IDA — iron deficiency anemia; IA - infectious anemia; IA + ID - infectious anemia with iron deficiency; CG - control group

Examined parameters: $\mathrm{Fe}$ — iron concentration; UIBC — unsaturated iron-binding capacity; TIBC — total iron-binding capacity;

TS index - transferrin saturation index

ues (Fe, UIBC, TIBC, TSI, ferritin concentration) in the examined groups of children. The same analysis was done in reference to the sTfR/logF; see Table 2 for results.

In the IDA group, a statistically significant relationship was found between both sTfR and the sTfR/ $/ \log \mathrm{F}$ and the above-mentioned parameters (proportional for UIBC and TIBC and inversely proportional for Fe and TSI). Those sTfR relationships were not found in any of the children from the other groups, while the sTfR/logF confirmed a relevant correlation between ferritin concentrations in children from all the groups, except the IDA group, most significantly expressed in children without iron deficit (IA and CG). Moreover, this index correlated with total and unsaturated iron-binding capacity in children with infectious anemia.

In order to evaluate the clinical value of serum soluble transferrin receptor concentrations and of the $\mathrm{sTfR} / \log \mathrm{F}$ values to differentiate IDA from IA, the sensitivity, specificity and accuracy were studied for each of the studied factors. The cut-off points were the upper and lower limits of the value ranges established for the CG children. In all the groups, the sensitivity of the sTfR concentration was $100 \%$ and the accuracy was above $90 \%$, although there were certain differences in the specificity, being above $90 \%$ in the IDA and IA and under $90 \%$ in the IA + ID children. The sensitivity, accuracy and specificity for the sTfR/logF were high i.e. over $90 \%$ (see Figure 2).

\section{Discussion}

Recognising anemia caused by iron deficiency requires an evaluation of the medical history of an individual patient, subject examination, and complex hematological and biochemical examinations. This statement is in accord with the opinions of other authors $[1,5-8]$.

Many authors emphasize the fact that there is no one single study that can inform about iron deficiency. Cook et al. [31], in population studies, proved that no single index, including TSI, ferritin concentration, or the level of protoporphyrin in erythrocytes, was a proper indicator of iron deficiency; they found that in $8.3 \%$ of healthy people, one of these parameters was incorrect.

However, Burns et al. [7] showed that among hospitalized patients, ferritin concentration gave the most effective estimation, with $90 \%$ of properly diagnosed iron deficiency cases, $84 \%$ for complete iron binding ability, $50 \%$ for the transferritin saturation index, and $41 \%$ for serum iron concentration vs. bone marrow bioptate evaluations. Punnonen et al. [30], in turn, while examining adults with iron deficiency anemia, found that in $95 \%$ of cases lowered serum ferritin concentrations correctly identified iron deficiency, as confirmed by bone marrow biopsy. But among patients with chronic inflammatory disease, proper serum ferritin concentrations did not exclude iron deficiency. Nevertheless, other authors have claimed transferrin saturation index below $16 \%$ to be the best iron deficiency indicator $[1,28]$. It should be noted that a relatively large variation of biochemical parameters, especially iron and ferritin concentrations and the transferrin saturation index, indicate a need for a simultaneous evaluation of several indices [32-34]. In our study, iron deficiency was identified in children also diagnosed with decreased serum iron concentrations, elevated unsaturated iron-binding capacity, TSI under $16 \%$ and low ferritin concentrations simultaneously. 

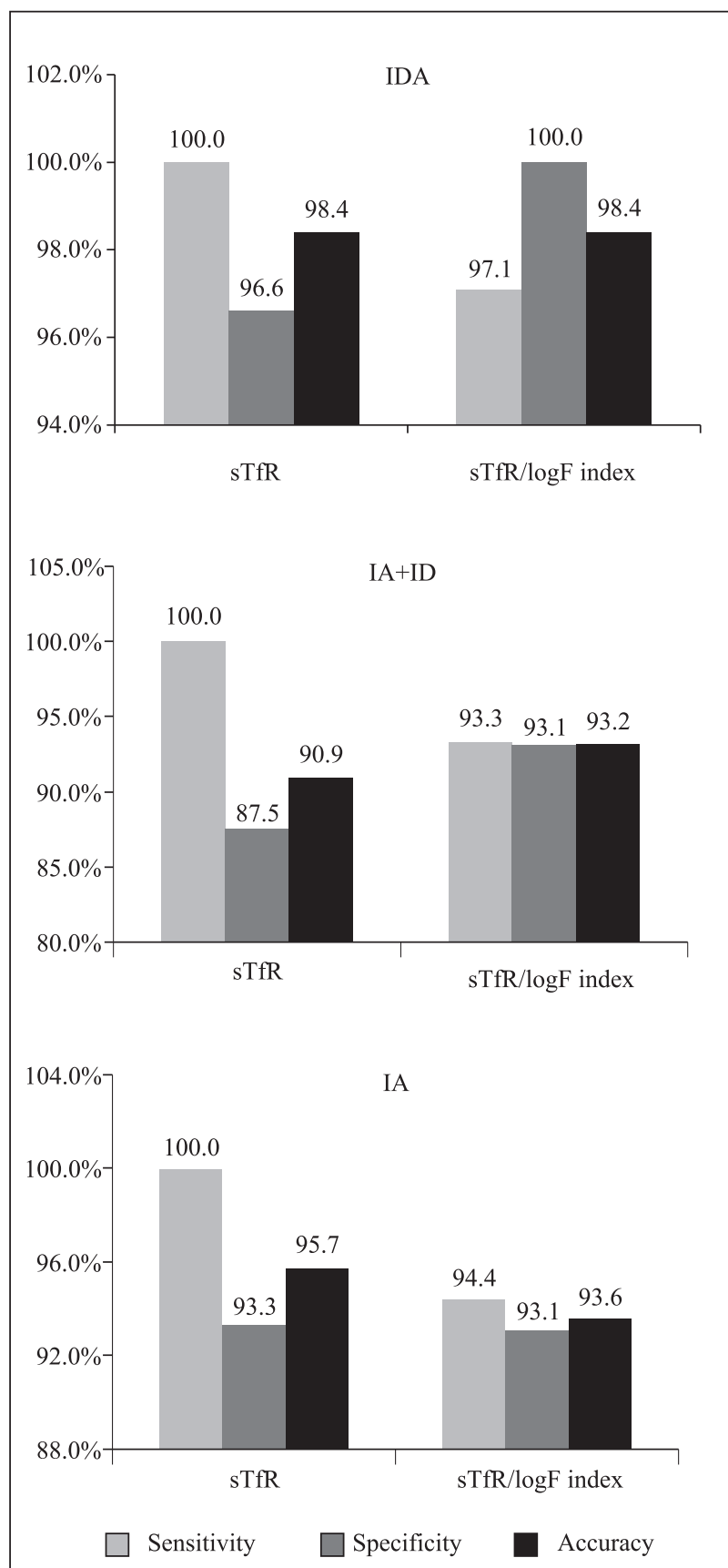

IDA - iron deficiency anemia; IA + ID — infectious anemia with iron deficiency; IA - infectious anemia

Cut-off point sTfR $2.49 \mathrm{mg} / \mathrm{dl}$.

Cut-off point sTfR/logF index 1.72

Figure 2. Sensitivity, specificity and accuracy for the soluble transferrin receptor (sTfR) and sTfR/logarithm of ferritin index (sTfR/logF index) in examined children

In addition, the challenges encountered in evaluating iron balance in infants and young children are connected with the need for a relatively large blood sample for complex laboratory tests. This inclines the authors to seek a single examination method to diag- nose iron deficiency. The problems with iron deficiency identification are heightened even further by the occurrence of acute or chronic infection and/or neoplastic disease $[7,9,35,36]$.

It has to be remarked that in the analyzed results of the children with anemia, no age or sex distinction was taken into account due to the lack of any difference concerning these two aspects in the CG children. This observation agrees with the results of other authors [3, 37-40].

Soluble transferrin receptor values in children with IDA were 2.4 times higher, and in patients with infectious anemia and iron deficiency (IA + ID) two times higher, than STfR values in IA and CG children. For sTfR/logF, which was 8.2 times higher in children with IDA and 3.7 times higher among the subjects with IA + ID, the same differences were found, although more strongly expressed. However, no sTfR differences were observed between IA and CG children. Also, it has to be remarked that sTfR/ $/ \log \mathrm{F}$ values were lower in IA children than in those from the comparator group, as a consequence of increased serum ferritin concentration in children in the former group during the course of disease.

Similar differences were observed in examinations of 1-6 year old children by Malope [41] and of 1-10 year old children by Angeles Vázquez López [26].

The results of examinations of other authors also demonstrate the usefulness of sTfR concentrations and sTfR/ $/ \log F$ values in differentiating IDA from IA, as no increase in either parameter was observed in patients with infectious anemia without iron deficiency [27, 42-44].

However, it has to be stated that anemia type differentiation solely by sTfR and sTfR/logF must be done carefully because, as proved by Wians et al. [45], sTfR and sTfR/logF can also be increased in children with infectious anemia. Similarly, among the subjects of the study, $10.5 \%$ of IA children demonstrated increases in both of these parameters.

Nevertheless, the correlation between sTfR concentrations, biochemical iron indices, especially those of iron and ferritin concentration in blood serum, total iron-binding capacity $[44,46,47]$ and TSI value $[44,48]$, indicate the usefulness of the soluble transferrin receptor assay in anemia type differentiation. A correlation analysis showed statistically significant relationships among sTfR and iron concentration, unsaturated iron-binding capacity and TSI only in IDA children. No such relationship was found in any children from either group without iron deficiency, corresponding to the results of Kohgo et al. [15]. Other authors have not shown any statistically significant correlations between sTfR and biochemical iron indices in healthy, growing boys [49] or in infants and young children [38]. 
These relationships confirm that soluble transferrin receptor increases with growing iron deficiency, but remains unchanged when iron stores are correct. Such a close relationship was not observed for the sTfR/logF.

The evaluated sensitivity, specificity and accuracy of sTfR and sTfR/logF indicate the possibility of their clinical usefulness in the differential diagnostics of anemia, as confirmed by the results of Wians et al. [45], Baillie et al. [50] and Olivares et al. [44]. In our study, the obtained sensitivity, accuracy and specificity was $100 \%,>90 \%$ and $>87 \%$, respectively for sTfR in both groups of children with anemia and iron deficiency, but all those parameters were over $90 \%$ for the sTfR/logF.

Moreover, it seems that the use of these assays in everyday pediatrics is legitimate, due to the relatively small blood sample required for particular assays. However, standardized age norms would be important for their broader clinical application.

\section{Conclusions}

1. This study demonstrated the usefulness of soluble transferrin receptor and its index in the differential diagnosis of anemia in young children.

2. The stated correlation between sTfR and the examined parameters of iron balance suggests that sTfR can be treated as a proper iron deficiency indicator.

3. Our results showed no differences in sTfR concentration in terms of either sex or age of the examined children.

4. The relatively low examination costs and small blood sample amounts make the sTfR assay useful in the differential diagnosis of anemia, especially in young children.

\section{References}

1. Dębiec B, Gołębiowska M, Godzisz J. Zachowanie się wskaźników hematologicznych i biochemicznych żelaza u dzieci łódzkich w wieku od 3 do 36 miesięcy. Przeglad Pediatr. 1981;11:332-342.

2. Kamer B, Dółka E, Świątkowska E, Kulig K, Michalecka J, Sujec$\mathrm{ka} \mathrm{K}$. Iron deficiency anaemia in infants and small children based on own experience. Przeglad Pediatr. 2006;36:215-217.

3. Bramhagen AC, Virtanen M, Siimes MA, Axelsson I. Transferrin receptor in children and its correlation with iron status and types of milk consumption. Acta Paediatr. 2003;92:671-675.

4. Wu AC, Lesperance L, Berstein H. Badania przesiewowe w kierunku niedoboru żelaza. Pediatria po Dyplomie. 2002;6:63-71.

5. Baynes RD. Assessment of iron status. Clin Biochem. 1996;29:209-215.

6. Baynes RD, Cook JD. Current issues in iron deficiency. Curr Opin Haematol. 1996;3:145-149.

7. Burns ER, Goldberg SN, Lawrence C, Wenz B. Clinical utility of serum tests for iron deficiency in hospitalized patients. Am J Clin Pathol. 1990;93:240-245.
8. Cook JD, Lipschitz DA, Miles LEM, Finch CA. Serum ferritin as a measure of iron stores in normal subjects. Am J Clin Nutr. 1974;27:681-687.

9. Feelders RA, Kuiper-Kramer EPA, van Eijk HG. Structure, function and clinical significance of transferrin receptors. Clin Chem Lab Med. 1999;37:1-10.

10. Seligman PA, Schleicher RB, Allen RH. Isolation and characterization of the transferrin receptor from human placenta. J Biol Chem. 1979;254:9943-9946.

11. Trowbridge IS, Newman RA, Domingo DL, Sauvage C. Transferrin receptors: structure and function. Biochem Pharmacol. 1984;33:925-932.

12. Bali PK, Zak O, Aisen P. A new role for the transferrin receptor in the release of iron from transferrin. Biochemistry. 1991;30:324-328.

13. Beguin Y. Soluble transferrin receptor for the evaluation of erythropoiesis and iron status. Clin Chim Acta. 2003;329: 9-22.

14. Huebers HA, Beguin Y, Pootrakul P, Einspahr D, Finch CA. Intact transferrin receptors in human plasma and their relation to erythropoiesis. Blood. 1990;75:102-107.

15. Kohgo Y, Niitsu Y, Kondo H et al. Serum transferrin receptor as a new index of erythropoiesis. Blood. 1987;70:1955-1958 .

16. Kohgo Y, Nishisato T, Kondo H, Tsushima N, Niitsu Y, Urushizaki I. Circulating transferrin receptor in human serum. $\mathrm{Br}$ J Haematol. 1986;64:277-281.

17. Baynes RD, Shih YJ, Hudson BG, Coook JD. Production of the serum form of the transferrin receptor by a cell membrane-associated serine protease. Proc Soc Exp Biol Med. 1993;204:65-69.

18. Shih YJ, Baynes RD, Hudson BG, Cook JD. Characterization and quantitation of the circulating forms of serum transferrin receptor using domain-specific antibodies. Blood. 1993;81:234-238.

19. Ahn J, Johnstone RM. Origin of a soluble truncated transferrin receptor. Blood. 1993;81:2442-2451.

20. R'zik S, Beguin Y. Serum soluble transferrin receptor concentration is an accurate estimate of the mass of tissue receptors. Exp Hematol. 2001;29:677-685.

21. Skikne BS, Flowers C, Cook JD. Serum transferrin receptor: A quantitative measure of tissue iron deficiency. Blood. 1990;75:1870-1876.

22. Mast A. The clinical utility of peripheral blood test in the diagnosis of iron deficiency anemia. Bloodline. 2001;1:7-9.

23. Ferguson BJ, Skikne BS, Simpson KM, Baynes RD, Cook JD. Serum transferrin receptor distinguishes the anemia of chronic disease from iron deficiency anemia. J Lab Clin Med. 1992;119:385-390.

24. Kivivuori SM, Heikinheimo M, Teppo AM, Siimes MA. Early rise in serum concentration of transferrin receptor induced by recombinant human erythropoietin in very-low-birthweight infants. Pediatr Res. 1994;36:85-89.

25. Zhu YI, Haas JD. Response of serum transferrin receptor to iron supplementation in iron-depleted, nonanemic women. Am J Clin Nutr. 1998;67;271-275.

26. Angeles Vázquez López M, Molinos FL et al. Serum transferrin receptor in children: usefulness for determinating the nature of anemia in infection. $J$ Pediatr Hematol Oncol. 2006;28:809-815.

27. Skikne BS, Punnonen K, Caldron PH et al. Improved differential diagnosis of anemia of chronic disease and iron deficiency anaemia: A prospective multicenter evaluation of soluble transferrin receptor and the sTfR/log ferritin index. $A m$ J Hematol. 2011;86:923-927. 
28. Lanzkowsky P. Hematologia i onkologia dziecięca. PZWL, Warszawa, 1994.

29. Dimitriou H, Stiakaki E, Markaki EA, Bolonaki I, Giannakopoulou Ch, Kalmanti M. Soluble transferrin receptor levels and soluble transferrin receptor/log ferritin index in the evaluation of erythropoietic status in childhood infections and malignancy. Acta Pcediatr. 2000;89:1169-1173.

30. Punnonen K, Irjala K, Rajamaki A. Serum transferrin receptor and its ratio to serum ferritin in the diagnosis of iron deficiency. Blood. 1997;89:1052-1057.

31. Cook JD, Finch CA, Smith NJ. Evaluation of the iron status of a population. Blood. 1976;48:449-455.

32. Ahluwalia N, Lammi-Keefe CJ, Haley NR, Beard JL. Dayto-day variation in iron status indexes in eldery women. $\mathrm{Am}$ J Clin Nutr. 1993;57:414-419.

33. Romslo I, Talstad I. Day-to-day variation in serum iron, serum iron binding capacity, serum ferritin and erythrocyte protoporfiryn concentrations in anaemic subjects. Eur J Haematol. 1988;40:79-82.

34. Borel MJ, Smith SM, Deer J, Beard JL. Day-to-day variation in iron-status indicies in healthy men and women. Am J Clin Nutr. 1991;54:729-735.

35. Coenen JL, van Dieijen-Visser MP, van Pelt J et al. Measurements of serum ferritin used to predict concentrations of iron in bone marrow in anemia of chronic disease. Clin Chem. 1991;37:560-563.

36. Mast AE, Blinder MA, Gronowski AM, Chumley C, Scott MG. Clinical utility of the soluble transferrin receptor and comparision with serum ferritin in several populations. Clin Chem. 1998;44:45-51.

37. Choi JW, Pai SH, Im MW, Kim SK. Change in transferrin receptor concentrations with age. Clin Chem. 1999;45:1562-1563.

38. Yeung GS, Zlotkin SH. Percentile estimates for transferrin receptor in normal infants 9-15 mo of age. Am J Clin Nutr. 1997;66:342-346.

39. Virtanen MA, Viinikka LU, Virtanen MKG et al. Higher concentrations if serum transferrin receptor in children than in adults. Am J Clin Nutr. 1999;69:256-260.

40. Suominen P, Virtanen A, Lehtonen-Veromaa $\mathrm{M}$ et al. Regression-based reference limits for serum transferrin recep- tor in children 6 months to 16 years of age. Clin Chem. 2001:47:935-937.

41. Malope BI, MacPhail AP, Alberts M, Hiss DC. The ratio of serum transferrin receptor and serum ferritin in the diagnosis of iron ststus. Br J Haematol. 2001;115:84-89.

42. Marković M, Majkić-Singh N, Subota V. Usefulness of soluble transferrin receptor and ferritin in iron deficiency and chronic disease. Scan J Clin Lab Invest. 2005;65:571-576.

43. Bhaskaram P, Madhavan Nair K, Balakrishna N, Ravinder P, Sesikeran B. Serum transferrin receptor in children with respiratory infections. Europ J Clin Nutr. 2003;57:75-80.

44. Olivares M, Walter T, Cook JD, Hertrampf E, Pizarro F. Usefulness of serum transferrin receptor and serum ferritin in diagnosis of iron deficiency in infancy. Am J Clin Nutr. 2000;72:1191-1195.

45. Wians FH, Urban JE, Keffer JH, Kroft SH. Discriminating between iron deficiency anemia and anemia of chronic disease using traditional indices of iron status vs transferrin receptor concentration. Am J Clin Pathol. 2001;115:112-118.

46. Maes M, Bosmans E, Scharpe $\mathrm{S}$ et al. Components of biological variation in serum soluble transferrin receptor: relationships to serum iron, transferrin, and ferritin concentrations, and immune and haematological variables. Scand J Clin Lab Invest. 1997;57:31-41.

47. Petterson T, Kivivuori SM, Siimes MA. Is serum transferrin receptor useful for detecting iron-deficiency in anaemic patients with chronic inflammatory diseases? Br J Rheumatol. 1994;33:740-744.

48. North M, Dallalio G, Donath AS, Melink R, Means RT jr. Serum transferrin receptor levels in patients undergoing evaluation of iron stores: correlation with other parameters and observed versus predicted results. Clin Lab Haematol. 1997;19:93-97.

49. Kivivuori SM, Anttila R, Viinikka L, Pesonen K, Siimes MA. Serum transferrin receptor for assessment of iron status in healthy prepubertal and early pubertal boys. Pediatr Res. 1993;34:297-299.

50. Baillie FJ, Morrison AE, Fergus I. Soluble transferrin receptor: a discriminating assay for iron deficiency. Clin Lab Haematol. 2003;25:353-357.

Submitted: 13 January, 2012 Accepted after reviews: 20 June, 2012 